\title{
Academy boosts US fishermen in tuna battle
}

Washington. A National Research Council (NRC) report on the Atlantic bluefin tuna seems likely to harden the negotiating position of the United States when it meets with European nations in Madrid in November to discuss the valuable fish.

The conclusions of the study by the NRC - the operating arm of the National Academy of Sciences - provide little comfort for conservationists seeking stricter controls on tuna fishing in the eastern Atlantic, because it found that stocks of the tuna in this area, where quotas are in force, have stabilized over the past six years.

But the report also found that there is considerable 'mixing' between the western stock, which breeds in the Gulf of Mexico, and the larger eastern stock, which is spawned in the Mediterranean. This conclusion (which has also upset conservationists) has been warmly welcomed by US fishermen, who want action to stop the unregulated harvesting of young tuna in the Mediterranean.

The bluefin tuna (Thunnu thynnus) is a large and remarkable fish that migrates northwards through the waters of many nations from its spawning grounds. It can grow up to 10 feet in length, and attracts premium prices of up to $\$ 10,000$ a fish in Japan, its main market. But immature fish are caught in huge numbers in the Mediterranean, and are subsequently canned as ordinary tuna.

Since 1982, the bluefin tuna has been managed by the Madrid-based International Commission for the Conservation of Atlantic Tunas (ICCAT) as two separate stocks, divided by the $45^{\circ}$ longitude, which stretches down from the tip of Greenland. According to US observers, this has led to a tight quota regime aimed at protecting the population in the eastern Atlantic, while fishing of the larger western population continues virtually without restriction.

But the NRC panel, chaired by John Magnuson of the University of Wisconsin, which has reviewed the scientific data, said last week that there is strong evidence of 'mixing' between the two stocks. The panel also found that the decline in the size of the western stock has been halted since 1988 .

The panel's report is likely to force ICCAT to abandon plans for tighter quotas for US fishermen in the western Atlantic. "This is the best thing that could have happened," says Richard Ruais, director of the East Coast Tuna Association based in Salem, New Hampshire. "We think the report will be of tremendous benefit to ICCAT and to the fishermen."

Congressman Gerry Studds (Democrat, Massachusetts), who was instrumental in getting government agencies to commis- sion the report, says he also expects the study to persuade ICCAT to take action to restrict fishing by European fishermen in the Mediterranean.

The US National Oceanic and Atmospheric Administration (NOAA) is now discussing the report's conclusions prior to deciding on what position to take at ICCAT's next meeting in November.

But not everyone in the United States agrees that the onus to conserve the bluefin

\section{IMAGE UNAVAILABLE FOR COPYRIGHT REASONS}

\section{uefin tuna: 'one stock not two' in north Atlantic.}

tuna should be shifted across the Atlantic. "These are two separate stocks, who breed in separate areas," insists Carl Safina of the National Audubon Society, a powerful conservation group. Jointly with other groups, the Audubon Society has issued a statement branding the report "inconsistent and inconclusive", and claiming that it "should not be used as an excuse to avoid additional con- servation measures in the western Atlantic by passing the buck to the eastern Atlantic and Mediterranean".

Magnuson characterizes the report as "a correction" to previous assessments. But he says that he does expect it to change the way ICCAT looks at managing the bluefin tuna, and also emphasizes the report's call for research to provide new data on fish stocks.

It is also clear from the report that much of the basic information, needed to determine whether there is in fact one stock of bluefin tuna rather than two, is not available. Scientists do not know whether the two stocks interbreed and what the stock levels are. Furthermore, they have only very hazy estimates of the 'mixing' that goes on across the Atlantic.

"Our analysis says that the population is stable [in the western Atlantic] but we don't know why," says Terry Quinn, a panel member from the University of Alaska. "It is almost appalling that the basic data needed for managing the population is not there."

Quinn's comments raise the issue of how the many governments with interests in a fish such as the bluefin tuna are ever going to agree and enforce management policies on the basis of scientific results that remain so uncertain. "They have to use the best available science," says Magnuson. "Many of the questions which. they might put to the scientists cannot be answered. We need better data - but its absence can't be used as an excuse not to use what we have."

Colln Macilwain

\section{Funds flow for eastern gene-banks}

Paris. Western aid is flowing into a US\$2.5 million plan, coordinated by the International Plant Genetic Resources Institute (IPGRI) - formerly the International Board for Plant Genetic Resources, based in Rome - to rescue more than half a million varieties of 2,500 plant species at risk in genebanks in eastern Europe and the former Soviet Union (see Nature 360, 201; 1992).

In particular, the United States has donated $\$ 400,000$ to help secure the 350,000 accessions held at the Vavilov Research Institute of Plant Breeding in St Petersburg, Russia, and its 17 experimental stations. The United Nations Development Programme has donated $\$ 25,000$, while the US Agency for International Development (AID) has pledged $\$ 500,000$ and France FFr500,000 (US\$93,450).

An immediate need has been to repair long-term storage facilities. In the longer term, says IPGRI, money will also have to be spent on modernizing the institute. Com- puting facilities will need to be improved, for example, to improve the dissemination of the information which has been carefully compiled and monitored.

Sweden has also donated $\$ 30,000$ for emergency repairs to Hungarian gene-banks, and Switzerland $\$ 42,000$ for those in Bulgaria. A $\$ 400,000$ project, coordinated by IPGRI and the Centre for Genetic Resources in the Netherlands - whose government is paying - will coordinate the development of a common documentation system in seven east European countries.

AID has also pledged $\$ 500,000$ to protect botanical specimens at the Komarov Botanical Institute in St Petersburg, whose plight was recently raised by British academics (see Nature 371, 9; 1994). For its part, the UK government has donated $\$ 30,000$ to duplicate a unique collection of onions and garlic (Allium sp.) held in Olomouc in the Czech Republic.

Declan Butler 